\title{
Transplant nephrectomy with peritoneal window: Georgetown University experience
}

\author{
Rachel Rubinz ${ }^{1}$, Oya M. Andaçoğlu ${ }^{2}$, Erik Anderson ${ }^{1}$, William Corder ${ }^{1}$, Evan Michaelson ${ }^{1}$, Jack Moore ${ }^{2}$, Matthew Cooper ${ }^{2}$, Seyed Ghasemian ${ }^{1,2}$ \\ 1 Department of Urology, Georgetown University School of Medicine, Washington, USA \\ ${ }^{2}$ Georgetown University MedStar Transplant Institute, Washington, USA
}

\begin{abstract}
Objective: Transplant nephrectomy is a technically challenging procedure with high complication rates. Morbidity and mortality are mostly due to hemorrhage or infection and are reported to be $17-60 \%$ and $1-39 \%$, respectively. The most common surgical technique for transplant nephrectomy is sub-capsular, extraperitoneal approach which may result in fluid accumulation and subsequent super-infection. We report that intraperitoneal approach, after assuring hemostasis of the transplant pedicle, allows for passive drainage, decreases hematoma formation and minimizes the subsequent infection risk in the nephrectomy bed.
\end{abstract}

Material and Methods: From July 2009 to July 2014 a total of 38 transplant nephrectomies were performed using the intraperitoneal window technique at Georgetown University MedStar Transplant Institute (MGTI). Data was collected retrospectively.

Results: Average age at the time of transplant nephrectomy was $43.9 \pm 14.3$, and the majority were male (55.3\%). Mean time to nephrectomy was 71.7 \pm 67.4 months following transplantation. Indications for nephrectomy included pain, hematuria, fever, and recalcitrant rejection. Average operative time was $97.1 \pm 28.9$ minutes, average blood loss was $172.5 \pm 213.6 \mathrm{~mL}$. A total of $9(24 \%)$ complications occurred. Postoperative blood transfusion was the most common complication (15.7\%) followed by $2(5.3 \%)$ re-interventions; one take back for hematoma and one percutaneous drain placement for symptomatic fluid collection. We had no infection, postoperative sepsis, ICU admissions, or mortality.

Conclusion: Transplant nephrectomy with peritoneal window is a technique with better results compared to the literature. An opening between the transplant cavity and the peritoneum allows for passive drainage of fluid and minimizes the risk of hematoma and abscess formation. This approach does not add significant time to the operation, furthermore it may decrease morbidity and mortality by reducing overall complications, namely hematoma formation and infection, which overall decreases rates of re-interventions and length of hospital stay.

Keywords: Nephrectomy, transplant, transperitoneal

Cite this article as: Rubinz $R$, Andaçoğlu OM, Anderson $E_{,}$ Corder W, Michaelson E, Moore J, Cooper M, Ghasemian S. Transplant nephrectomy with peritoneal window: Georgetown University institution experience. Turk J Surg 2019; 35 (3): 191-195

\section{Corresponding Author}

Oya M. Andaçoğlu

E-mail: o.andacoglu@me.com

Received: 04.04.2018

Accepted: 03.09 .2018

Available Online Date: 23.09.2019

O Copyright 2019 by Turkish Surgical Society Available online at www.turkjsurg.com

DOI: $10.5578 /$ turkjsurg.4122

\section{INTRODUCTION}

Renal transplant has a failure rate of $12-22 \%$ by three years, and $44-59 \%$ by 10 years (1). A failed transplant provokes an inflammatory response which increases morbidity and mortality. It also incites symptomatic intolerance in patients $(2,3)$. Therefore, anywhere between $4.5-84 \%$ of those failed renal grafts require transplant nephrectomy (4). Although there are different opinions on the timing of transplant nephrectomy, current consensus is that removal of the failed graft is appropriate when symptoms are intractable (4-8).

The most common indication for transplant nephrectomy is symptomatic chronic rejection (58.2\%) which can cause graft tenderness, hematuria, fever, and persistent anemia $(9,10)$. An obvious benefit of nephrectomy is the relief of symptoms from allograft rejection or failure. Lopez-Gomez et al. have demonstrated attenuated inflammatory response after removal of a failed allograft when compared to failed graft patients treated with hemodialysis only. They have found decreased inflammatory markers, improved hypoalbuminemia, and decreased erythropoietin resistance (2). Additionally, Ayus et al. have reviewed 10.951 patients and reported that transplant nephrectomy improves survival after graft failure. After adjusting for socioeconomic status, comorbidities and donor characteristics, a 32\% decrease in all-cause mortality has been found in transplant nephrectomy group compared to patients keeping the failed allograft (11). 
Although transplant nephrectomy has been shown to improve survival and relieve symptoms after failed kidney transplant, it remains a technically demanding procedure that carries high morbidity (17-60\%) and mortality (1.5-14\%) due the poor health and comorbid conditions that often accompany transplant patients as well as operative complications (11-13). Alberts et al. have reviewed 157 transplant nephrectomies performed from 2000 to 2012, indicating 32 surgical complications (20\%), with postoperative bleeding, hematoma formation, and infection being the most common causes. Surgical re-intervention was necessary in $10 \%$ of the cases. Other reported complications are colonic perforation, cardio-pulmonary complications, and sepsis $(1,15)$.

The most commonly performed surgical technique for transplant nephrectomy is subcapsular extra peritoneal approach. Performing the procedure in a closed extraperitoneal space may result in fluid accumulation and subsequent infection. Immune-compromised patients are inevitably prone to develop septic complications in the presence of hematoma or seroma.

We hypothesize that creating an intraperitoneal window, after assuring hemostasis of the transplant pedicle, allows for passive drainage, decreases hematoma formation and minimizes the risk of infection, sepsis, and the need for re-interventions.

\section{MATERIAL and METHODS}

From July 2009 to July 2014, a total of 38 transplant nephrectomies using the intraperitoneal window technique were performed by two transplant surgeons at Medstar Georgetown Transplant Institute. IRB approval was obtained. Inclusion criteria for the study was any adult patient with prior kidney transplant undergoing transplant nephrectomy. Patient data was collected

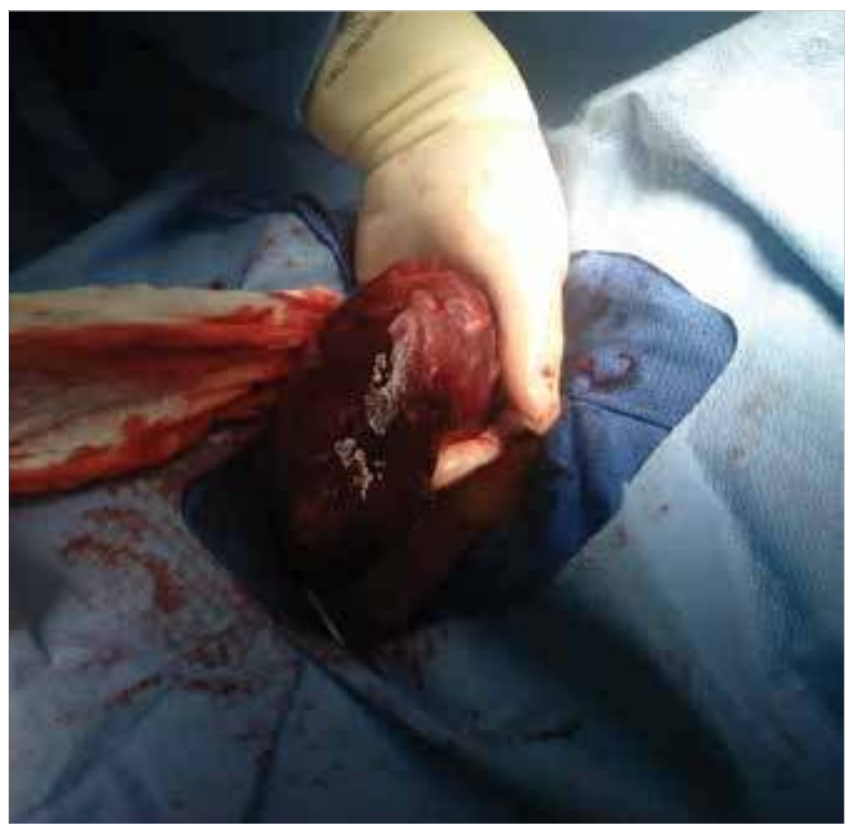

Figure 1. The allograft is enucleated from the renal capsule attached only with the renal pedicle. retrospectively, including patient characteristics, allograft characteristics, nephrectomy indications, operative data, hospital course, and complications

All transplant nephrectomies were performed using the standard subcapsular approach (Figure 1). We modified the standard double layer pedicle closure. Following excision of the specimen from the pedicle, any visible vessel was closed with figure of eight using \#2-0 silk suture (Figure 2). This was followed with a double layer of running \#2-0 prolene suture (Figure 3). In order to achieve adequate hemostasis, any capsular bleeding was controlled with electrocautery. Following this, the peritoneal window was created. The window was made large enough to avoid risk of internal hernia formation and bowel entrapment (Figure 4). Postoperative surgical complications were the primary outcome, and complications were graded using the Clavien-Dindo System (17).

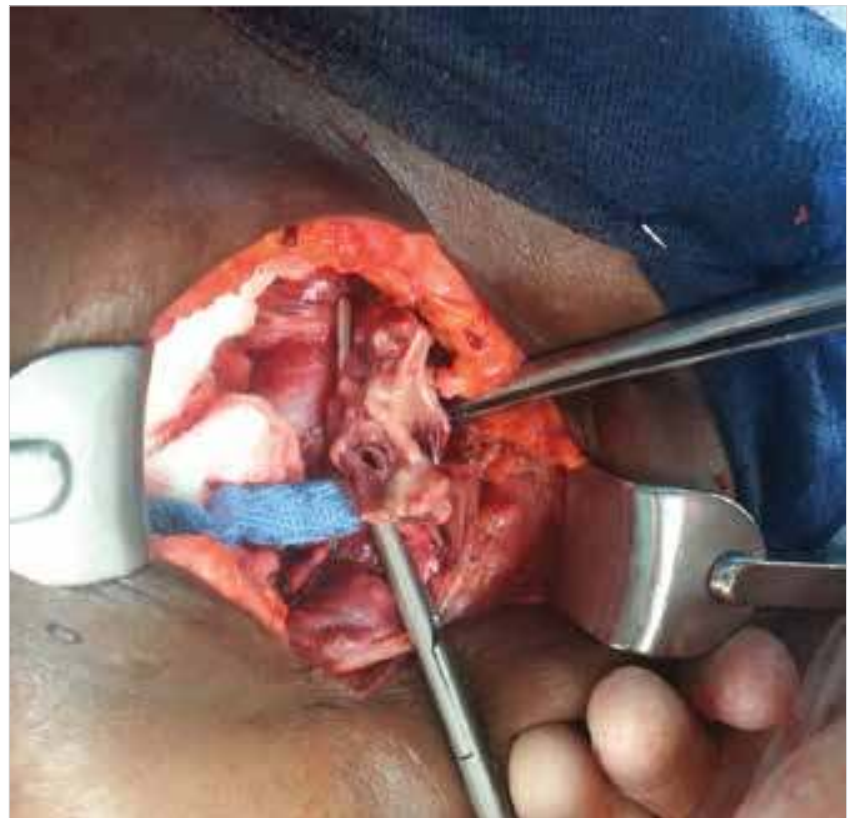

Figure 2. The pedicle is controlled with a vascular clamp and graft is excised.

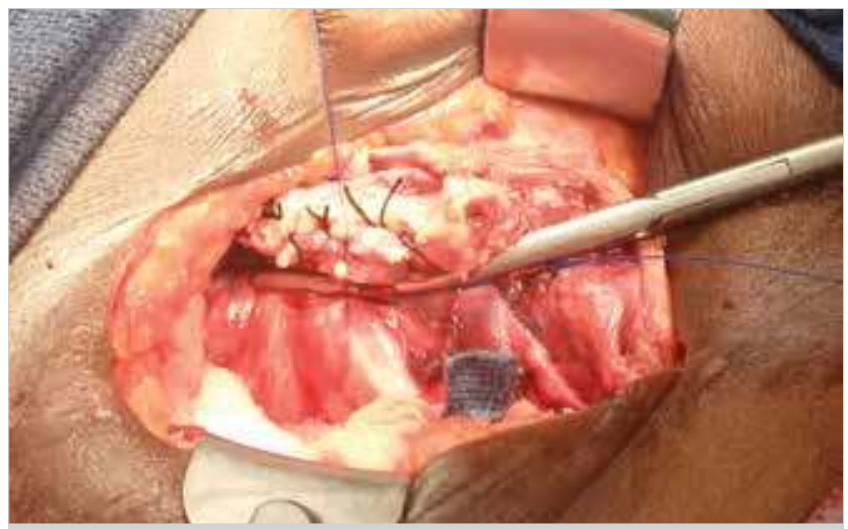

Figure 3. Control of the pedicle. Visible vessels are sutured with figure of eight, using \#2-0 silk followed by running \#2-0 Prolene. 


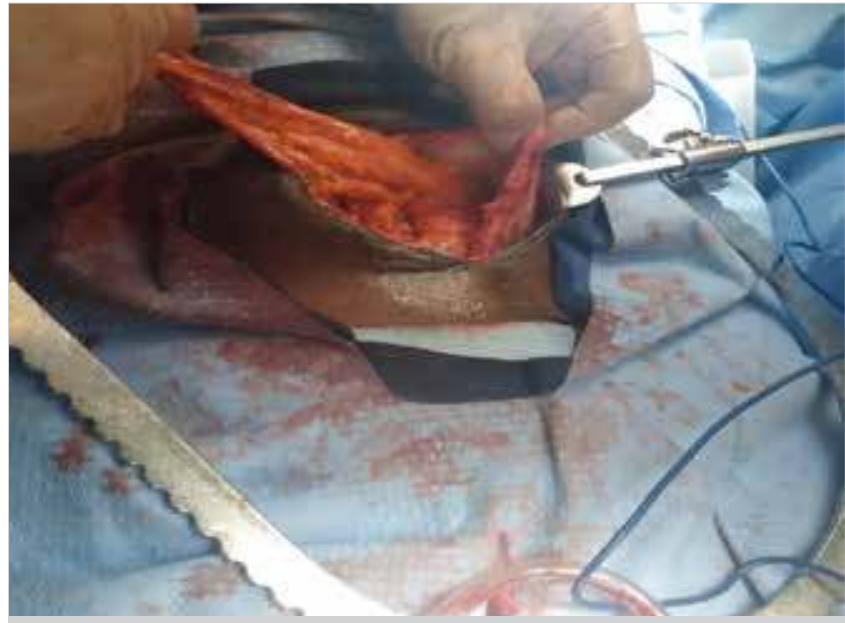

Figure 4. Creation of the peritoneal window. The peritoneum is incised along the length of the incision.

\section{RESULTS}

A total of 38 patients underwent transplant nephrectomy with the technique described in the 'methods' section. The average age of the patients was $43.92 \pm 14.3$ years and $55.3 \%$ of the patients were male (Table 1). Indications for nephrectomy included persistent and symptomatic acute and chronic transplant

Table 1. Patient characteristics

\begin{tabular}{|l|c|}
\hline Characteristics & $\mathbf{N}=\mathbf{3 8}(\mathbf{\%})$ \\
\hline Age & $43.92 \pm 14.30$ \\
\hline Male & $21(55.3)$ \\
\hline Comorbidities \\
\hline DM & $17(44.7)$ \\
\hline HTN & $36(94.7)$ \\
\hline CAD & $2(5.3)$ \\
\hline CVA & $1(2.6)$ \\
\hline COPD & $2(5.3)$ \\
\hline Malignancy & $2(5.3)$ \\
\hline Hepatitis C & $3(7.8)$ \\
\hline Time to nephrectomy (months) & $71.76 \pm 67.47$ \\
\hline $\begin{array}{l}\text { DM: Diabetes mellitus, HTN: Hypertension, CAD: Coronary artery disease, CVA: } \\
\text { Cerebrovascular accident, COPD: Chronic obstructive pulmonary disease. }\end{array}$ \\
\hline
\end{tabular}

Table 2. Indication for nephrectomy

\begin{tabular}{|l|c|}
\hline Indication for nephrectomy & $\mathbf{N}=\mathbf{3 8}(\mathbf{\%})$ \\
\hline Fever & $10(26.3)$ \\
\hline Pain & $27(71.0)$ \\
\hline Hematuria & $22(57.9)$ \\
\hline Leukocytosis & $2(5.3)$ \\
\hline
\end{tabular}

\begin{tabular}{|l|c|}
\hline Table 3. Operative data \\
\hline Operative data & $\mathbf{N = 3 8}(\mathbf{\% )}$ \\
\hline Operative time (minutes) & $97.1 \pm 28.9$ \\
\hline Estimated blood loss $(\mathrm{mL})$ & $172.5 \pm 213.6$ \\
\hline Hospital stay (days) & $3.08 \pm 1.7$ \\
\hline
\end{tabular}

rejection, with fever (26.3\%), pain (71.0\%), hematuria (57.9\%), leukocytosis (5.3\%) (Table 2). The average time from transplant to nephrectomy was $71.76 \pm 67.47$ months. Operative time was average of $97.1 \pm 28.9$ minutes with an average estimated blood loss of $172.5 \pm 213.6 \mathrm{~mL}$. Mean length of hospital stay was $3 \pm$ 1.7 days (Table 3 ).

A total of 9 (24\%) complications occurred. Postoperative blood transfusion was the most common complication (15.7\%). Two (5.6\%) patients required re-intervention: one take back to operating room for hematoma wash out, one patient required percutaneous drain placement for symptomatic fluid collection. Other complications included fever (1), pneumonia (1) and ileus (1). No infections, post-operative sepsis, ICU admissions, or mortalities occurred. A total of $18.4 \%$ patients had low grade (Clavien-Dindo class 1 and 2) complications, whereas high grade complications (Clavien-Dindo class 3 or higher) occurred in 5.2\% patients (Table 4).

\section{DISCUSSION}

Intraperitoneal window formation during transplant nephrectomy is a novel surgical approach designed to reduce complications and decrease morbidity and mortality. We believe creating a passage for passive fluid drainage from the nephrectomy cavity into the peritoneal cavity decreases the rate of fluid collection as well as infection risk, which are the two most common complications that occur after transplant nephrectomy.

Previous studies have discussed a wide variety of complication rates, ranging from $17 \%-60 \%$ (3). Three studies were focused for comparison of transplant nephrectomy complications. Mazzucchi et al. reported 70 transplant nephrectomies between 1994 and 2002 , with $18.5 \%$ of complication rate with $8.6 \%$ hematoma formations, $10 \%$ fluid collections, $7.1 \%$ infections, $10 \%$ re-interventions, and $1.4 \%$ mortality. Additionally, $44.3 \%$ of patients received blood transfusions, which was not classified as a complication in the study and would increase the complication rate considerably if this was included (18).

Similarly, Secin et al. reviewed 91 transplant nephrectomies from 1970 to 2000, reporting 48.3\% complication rate, including $15.4 \%$ hematoma formation, $9.9 \%$ fever, $7.6 \%$ sepsis, $4.4 \%$ wound infection, $10.9 \%$ re-interventions, and these were all were for either hematoma formation or infection. They had $7 \%$ mortality rate (4). 
Table 4. Complications

\begin{tabular}{|l|c|c|}
\hline Complications & $\mathbf{N = 3 8 ( \% )}$ & \\
\hline Total no. of complications & $9(23.7)$ & \\
\hline Infection & $0(0)$ & \\
\hline Hematoma & $1(2.6 \%)$ & \\
\hline Reintervention & $2(5.2 \%)$ & Actual Event \\
\hline Mortality & $0(0)$ & Ileus \\
\hline Complications grading according to Clavien-Dindo system & $\mathbf{N = 3 8 ( \% )}$ & Blood transfusion intraoperative, fever, pneumonia \\
\hline Grade I & $1(2.6 \%)$ & 1 take back to OR, 1 drain placement \\
\hline Grade II & $6(15.7 \%)$ & $2(5.2 \%)$ \\
\hline Grade III & & \\
\hline
\end{tabular}

Lastly Alberts et al. reported 25\% complication rate for 157 transplant nephrectomies from 2000-2012, with 9\% infection rate, $14 \%$ hematoma rate, and $10 \%$ rate of re-intervention, most of which was for hematoma formation. Mortality rate was 3.2\% (1).

When compared to our 38 patients with intraperitoneal windows, all three studies had much higher rates of complications, hematoma formations and fluid collections, infections, as well as re-intervention rate and mortality (Table 5).

Peritoneal window formation is an additional step in the surgical procedure that adds minimal amount of time to the total operation. In fact, the 38 nephrectomies with intraperitoneal window formation had a shorter average operative time (97.1 vs. 109.39 minutes), lower average estimated blood loss (172.5 vs. $509.2 \mathrm{~mL}$ ), and shorter average hospital stay (3 vs. 7 days) than previously reported studies. Potential downsides of this technique could be bleeding into the peritoneal cavity, which is much harder to tamponade compared to the retroperitoneal space, therefore we advocate meticulous hemostasis. Other potential risk may be bowel obstruction; however, we advocate large opening of the peritoneum in order to minimize this risk.

Limitations of this study include small sample size, and inherent limitations of a retrospective analysis without control cohort.

In conclusion, intraperitoneal window formation is a novel surgical technique for transplant nephrectomy that adds minimal time to the operation and appears to have a much lower morbidity and mortality rate.

Prospective and controlled studies are necessary in order to obtain more reliable results; however, low levels of complications and zero mortality observed in this series compared to literature is suggestive of possibly superior outcome of this technique.

Ethics Committee Approval: Institutional Review Board (IRB) approval was obtained.
Informed Consent: Due to the retrospective design of the study, the informed consent was not obtained.

Peer-review: Externally peer-reviewed.

Author Contributions: Consept - M.C., S.G.; Design - M.C., S.G., O.M.A.; Supervision - M.C., S.G.; Resource - R.R., E.A., W.C., E.M., J.M.; Materials - R.R., E.A., W.C., E.M., J.M.; Data Collection and/or Processing - R.R., O.M.A., E.A., W.C., E.M., J.M.; Analysis and Interpretation - O.M.A., S.G., M.C.; Literature Search - R.R., E.A., W.C., E.M.; Writing Manuscript - R.R., O.M.A., S.G.; Critical Reviews - M.C., S.G., O.M.A.

Conflict of Interest: The authors have no conflicts of interest to declare.

Financial Disclosure: The authors declared that this study has received no financial support.

\section{REFERENCES}

1. Alberts VP, Minnee RC, Bemelman FJ, van Donselaar-van der Pant KAMI, Idu MM. Transplant nephrectomy: what are the surgical risks? Ann Transplant 2013; 18: 174-81. [CrossRef]

2. Lopez-Gomez JM, Perez-Flores I, Jofre R, Carretero D, Rodriguez-Benitez $P$, Villaverde $M$, et al. Presence of a failed kidney transplant in patients who are on hemodialysis is associated with chronic inflammatory state and erythropoietin resistance. J Am Soc Nephrol 2004; 15:2494-501. [CrossRef]

3. Akoh JA. Transplant nephrectomy. World J Transplant 2011; 1: 4-12. [CrossRef]

4. Secin FP, Rovegno AR, del Rosario Brunet M, Marrugat REJ, Michel MD, Fernandez H. Cumulative Incidence, indications, morbidity and mortality of transplant nephrectomy and the most appropriate time for graft removal: only nonfunctioning transplants that cause intractable complications should be excised. J Urol 2003; 169: 1242-6. [CrossRef]

5. Zargar MA, Kamali K. Reasons for transplant nephrectomy: a retrospective study of 60 cases. Transplant Proc 2001; 33: 2655-6. [CrossRef]

6. Dinis $P$, Nunes $P$, Marconi L, Furriel F, Parada B, Moreira P, et al. Kidney retransplantation: removal or persistence of the previous failed allograft? Transplant Proc 2014; 46: 1730-4. [CrossRef]

7. Sharma DK, Pandey AP, Nathnan V, Gopalakrishnan G. Allograft nephrectomy-a 16-year experience. Br J Urol 1989; 64: 122-4. [CrossRef]

8. Toledo-Pereyra LH, Gordon C, Kaufmann R, Whitten JI, Mittal VK. Role of immediate vs delayed nephrectomy for failed renal transplants. Am Surg 1987; 53: 534-6. 
9. Noel C, Hazzan M, Boukelmoune M, Jaillard S, Dufosse F, Codaccioni $M X$, et al. Indication for allograft nephrectomy after irreversible rejection: is there an ideal delay? Transplant Proc 1997; 29: 145-6. [CrossRef]

10. Messa P, Ponticelli C, Berardinelli L. Coming back to dialysis after kidney transplant failure. Nephrol Dial Transplant 2008; 23: 2738-42. [CrossRef]

11. Ayus JC, Achinger SG, Lee S, Sayegh MH, Go AS. Transplant nephrectomy improves survival following a failed renal allograft. J Am Soc Nephrol 2010; 21:374-80. [CrossRef]

12. Khakhar AK, Shahinian VB, House AA, Muirhead N, Hollomby DJ, Leckie $S H$, et al. The impact of allograft nephrectomy on percent panel reactive antibody and clinical outcome. Transplant Proc 2003; 35: 862-3. [CrossRef]

13. Lair D, Coupel S, Giral M, Hourmant M, Karam G, Usal C, et al. The effect of a first kidney transplant on a subsequent transplant outcome: an experimental and clinical study. Kidney Int 2005; 67:2368-75.

[CrossRef]
14. Pham PT, Everly M, Faravardeh A, Pham PC. Management of patients with a failed kidney transplant: Dialysis reinitiation, immunosuppression weaning, and transplantectomy. World J Nephrol 2015; 4: 14859. [CrossRef]

15. Johnson O, Rose C, Landsberg D, Gourlay WA, Gill JS. Nephrectomy after transplant failure: current practice and outcomes. Am J Transplant 2007; 7: 1961-7. [CrossRef]

16. Kaplan B, Meier-Kriesche HU. Death after graft loss: an important late study endpoint in kidney transplantation. Am J Transplant 2002; 2: 970-4. [CrossRef]

17. Dindo D, Demartines N, Clavien PA. Classification of surgical complications: a new proposal with evaluation in a cohort of 6336 patients and results of a survey. Ann Surg 2004; 240: 205-13. [CrossRef]

18. Mazzucchi E, Nahas WC, Antonopoulos IM, Piovesan AC, lanhez LE, Arap S. Surgical complications of graft nephrectomy in the modern transplant era. J Urol 2003; 170: 734-7. [CrossRef]

\section{ORIJINAL ÇALIŞMA-ÖZET}

Turk J Surg 2019; 35 (3): 191-195

\section{Peritoneal drenaj ile transplant nefrektomi: Georgetown Üniversitesi sonuçları}

Rachel Rubinz ${ }^{1}$, Oya M. Andaçoğlu², Erik Anderson ${ }^{1}$, William Corder ${ }^{1}$, Evan Michaelson¹, Jack Moore², Matthew Cooper², Seyed Ghasemian ${ }^{1,2}$

1 Georgetown Üniversitesi Tıp Fakültesi, Üroloji Bölümü, Washington, Amerika Birleşik Devletleri

${ }^{2}$ Georgetown Üniversitesi Medstar Transplant Enstitüsü, Washington, Amerika Birleşik Devletleri

\section{ÖZET}

Giriş ve Amaç: Transplant nefrektomisinin morbidite ve mortalitesi \%60 ve \%39'a kadar çıkmakta olup genellikle kanama, enfeksiyon veya sepsise bağlı gelişmektedir. En çok kullanılan teknik subkapsüler, ekstraperitoneal yaklaşımdır. Bu yaklaşım seroma ya da hematom birikimini, dolayısıyla enfeksiyon riskini yükseltebilmektedir.

Gereç ve Yöntem: Temmuz 2009-Temmuz 2014 tarihleri arasında, Georgetown Üniversitesi MedStar Transplant Enstitüsü (MGTI)'nde 38 transplant nefrektomi olgusu gözden geçirildi. Retrospektif data analizi uygulandı.

Bulgular: Toplam 9 (\%24) komplikasyon gelişti. Transfüzyon en sık görülen komplikasyon idi $(\% 15,7)$ ve $2(\% 5,3)$ hastaya yeniden girişim yapıldı. Enfeksiyon, sepsis, yoğun bakım yatışı ya da ölüm gözlenmedi.

Sonuç: İntraperitoneal tekniğin pasif drenaj ve/veya absorbsiyon yolu ile hematom ya da enfeksiyon oluşumunu, dolayısıyla mortalite ve morbiditeyi azalttığı görüşündeyiz.

Anahtar Kelimeler: Nefrektomi, transplant, transperitoneal

Doi: $10.5578 /$ turkjsurg. 4122 